\title{
Pengaruh kurs, net ekspor, dan penanaman modal asing terhadap pertumbuhan ekonomi Indonesia
}

\author{
Tuty Cahya Azizah*; Haryadi; Etik Umiyati \\ Prodi Ekonomi Pembangunan, Fak. Ekonomi dan Bisnis.Universitas Jambi \\ *E-mail korespondensi:tutycahyaazizah@yahoo.co.id.
}

\begin{abstract}
The purpose of this study is to analyze the development of exchange rates, net exports, FDI, and Indonesia's economic growth in 1998-2017 and to analyze the effect of exchange rates, net exports, and foreign investment (FDI) on Indonesia's economic growth in 1998-2017. used in this study is secondary data sourced from the Central Statistics Agency (BPS). The analytical tool used in this study is descriptive and quantitative analysis, namely by multiple linear regression. The research method used in this study is the "Ordinary Least Square (Ordinary Least Square) method. OLS). The test results using OLS show that together the variables of the exchange rate, net exports, and FDI have a significant effect on Indonesia's economic growth. While partially, the exchange rate has a positive and significant effect on Indonesia's economic growth. Meanwhile, net exports have a positive and significant impact on Indonesia's economic growth. Meanwhile, FDI has a positive and significant impact on Indonesia's economic growth.
\end{abstract}

Keywords: Exchange rate, Net exports, Foreign investment, Economic growth.

\begin{abstract}
Abstrak
Tujuan dari penelitian ini adalah untuk menganalisis perkembangan kurs, net ekspor, PMA, serta pertumbuhan ekonomi Indonesia tahun 1998-2017 dan untuk menganalasis pengaruh kurs, net ekspor, dan penanaman modal asing (PMA) terhadap pertumbuha ekonomi Indonesia tahun 1998-2017.Data yang digunakan dalam penelitian ini adalah data sekunder yang bersumber dari Badan Pusat Statistik (BPS).Alat analisis yang digunakan dalam penelitian ini adalah analisis deskriptif dan kuantitatif, yaitu dengan regresi linear berganda.Metode penelitian yang digunakan dalam penelitian ini adalah metode "Ordinary Least Square (OLS).Hasil pengujian menggunakan OLS menunjukkan bahwa secara bersama-sama variabel kurs, net ekspor, dan PMA terhadap pertumbuhan ekonomi Indonesia berpengaruh signifikan. Sedangkan secara parsial, kurs berpengaruh positif dan signifikan terhadap pertumbuhan ekonomi Indonesia.Sementara net ekspor berpengaruh positif dan signifikan terhadap pertumbuhan ekonomi Indonesia.Sedangkan PMA berpengaruh positif dan signifikan terhadap pertumbuhan ekonomi Indonesia.
\end{abstract}

Kata kunci: Kurs, Net ekspor, Penanaman modal asing (PMA), Pertumbuhan ekonomi.

\section{PENDAHULUAN}

Pertumbuhan ekomomi adalah salah satu indikator yang sangat penting dalam 
melakukan analisis tentang pembangunan ekonomi yang terjadi pada suatu negara.(Zakaria, 2009).Salah satu negara yang berupaya meningkatkan pertumbuhan ekonomi negaranya adalah Indonesia.Pertumbuhan ekonomi bagi negara Indonesia sebagai negara berkembang, merupakan tujuan yang harus dicapai dalam pelaksanaan pembangunan (Diar, 2017).Semakin tinggi pertumbuhan ekonomi suatu negara, semakin tinggi pula kemampuan suatu negara untuk memenuhi kebutuhan masyarakat, sehingga akan semakin tinggi juga kemampuan suatu negara untuk mensejahterakan masyarakat.Kesejahteraan dalam jangka panjang tercermin pada peningkatan output perkapita yang sekaligus memberikan alternatif pada masyarakat dalam mengkonsumsi barang dan jasa serta diikuti daya beli masyarakat yang semakin meningkat (Purwanggono, 2015).

Berdasarkan data Badan Pusat Statistik (BPS), pertumbuhan ekonomi Indonesia pada tahun 2011 sebesar 6,49\%, menurun hingga tahun 2015, yaitu pada tahun 2012 sebesar 6,26\%, pada tahun 2013 sebesar 5,73\%, pada tahun 2014 sebesar 5,01\%, dan pada tahun 2015 sebesar $4,88 \%$. Selanjutnya meningkat lagi pada tahun 2016-2017 sebesar 5,03\% menjadi 5,07\% (BPS Nasional, 2018).Pertumbuhan ekonomi Indonesia berfluktuasi diantaranya dipengaruhi oleh net ekspor (total ekspor dikurangi total impor), kurs, dan penanaman modal asing. Berikut data pertumbuhan ekonomi, kurs, net ekspor, dan penanaman modal asing tahun 2011-2017, yaitu :

Tabel 1. Data pertumbuhan ekonomi, kurs, net ekspor, dan penanaman modal asing (PMA) Tahun 2011-2017.

\begin{tabular}{ccccc}
\hline Tahun & $\begin{array}{c}\text { Pertumbuhan } \\
\text { Ekonomi }(\%)\end{array}$ & $\begin{array}{c}\text { Kurs } \\
\text { (Rupiah) }\end{array}$ & $\begin{array}{c}\text { Net Ekspor } \\
\text { (Juta US\$) }\end{array}$ & PMA (Juta US\$) \\
\hline 2011 & 6,49 & 9068 & 26061,00 & 19474,50 \\
2012 & 6,26 & 9670 & $-1669,20$ & 24564,70 \\
2013 & 5,73 & 12189 & $-4076,90$ & 28617,50 \\
2014 & 5,01 & 12440 & $-2198,80$ & 28529,60 \\
2015 & 4,88 & 13795 & 7671,50 & 29275,90 \\
2016 & 5,03 & 13436 & 9533,40 & 28964,10 \\
2017 & 5,07 & 13548 & 11842,70 & 32239,80 \\
\hline
\end{tabular}

Sumber : BPS Nasional 2018

Data net ekspor Indonesia pada tahun 2011 sebesar U\$ 26.061,00. Selanjutnya pada tahun 2012-2014, impor lebih besar daripada ekspor, pada tahun 2012 sebesar U\$ - 1.669, tahun 2013 meningkat menjadi U\$ -4.076,90, dan tahun 2014 menurun kembali menjadi U\$ -2.198,80.Kemudian pada tahun 2015 meningkat menjadi U\$ 7.671,50 dan pada tahun 2016 meningkat kembali menjadi U\$ 9.533,40.Sedangkan pada tahun 2017 meningkat lagi menjadi U\$ 11.842,70.Jika total ekspor lebih besar daripada total impor, maka net ekspor akanmeningkatkan pertumbuhan ekonomi. Sebaliknya, jika total ekspor lebih kecil daripada impor, maka net ekspor akan menurunkan pertumbuhan ekonomi Indonesia.

Perkembangan kurs rupiah terhadap dollar Amerika Serikat pada tahun 2011 sebesar Rp 9.068,-. Kemudian terdepresiasi dari tahun 2012 ke tahun 2013 yaitu sebesar Rp 9.670,- menjadi Rp12.189,-. Pada tahun 2014 terdepresiasi lagi menjadi Rp 12.440,- dan pada tahun 2015 terdepresiasi kembali menjadi Rp 13.795,-. Tahun 2016 terapresiasi menjadi Rp 13.436,- dan pada tahun 2017 terdepresiasi menjadi RP 13.548 
(BPS Nasional, 2018). Depresiasi kurs tersebut dapat berdampak negatif pada perdagangan internasional, seperti kenaikan biaya produksi sebagai bagian dari input produksi. Selain itu, akan berdampak pada cadangan devisa akan menurun kemudian dapat menyebabkan pertumbuhan dan pembangunan ekonomi terhambat. Apabila kurs terus terdepresiasi, kondisi ini akan mempengaruhi pertumbuhan ekonomi Indonesia (Nugroho, 2016).

Investasi merupakan faktor yang penting dalam menentukan pertumbuhan ekonomi (Kurniasari, 2011).Bentuk investasi sendiri salah satunya adalah penanaman modal asing (PMA). Data PMA di Indonesia berfluktuasi, pada tahun 2011 sebesar US\$ 19.474,50, kemudian meningkat lagi tahun 2012 sebesar U\$24.564,70, tahun 2013 meningkat menjadi U\$28.617,50. Selanjutnya pada tahun 2014 menurun menjadi U\$28.529,60. Tahun 2015 meningkat menjadi U\$29.275,90 kemudian menurun kembali pada tahun 2016 sebesar U\$28.964,10. Pada tahun 2017 meningkat kembali menjadi U\$ 32.239,80 (BPS Nasional, 2018).Peran PMA sangat penting dalam kegiatan ekonomi, seperti untuk mencukupi kebutuhan barang dan jasa di beberapa sektor serta meningkatkan kesempatan kerja.Berbagai upaya dilakukan pemerintah untuk meningkatkan PMA di Indonesia.Upaya tersebut diantaranya dengan memberikan kemudahan-kemudahan sistem kerjasama dengan pengusaha domestik, dan jaminan keamanan, dengan harapan ketika PMA meningkat, maka pertumbuhan ekonomi Indonesia pun menjadi meningkat.

Data BPS menunjukkan pertumbuhan ekonomi Indonesia selama 20 tahun, yaitu dari 1998-2017 berfluktuasi. Pertumbuhan ekonomi dipengaruhi oleh bermacam faktor sesuai porsinya, seperti kurs, net ekspor, dan PMA.Berdasarkan data BPS pertumbuhan PMA dari tahun 1998-2017 juga berfluktuasi, seperti pada tahun 20112013 data penanaman modal luar negeri meningkat.Namun, ternyata tidak diikuti dengan peningkatan pertumbuhan ekonomi Indonesia, seperti pada tahun 2011-2013 dimana pertumbuhan ekonomi terus menurun. Sedangkan menurut teori, ketika PMA meningkat, maka diharapakan akan mendorong pertumbuhan sektor swasta dan rumah tangga dalam mengalokasikan sumber daya yang ada di suatu negara, dan akan meningkatkan pertumbuhan ekonomi. Oeh karena itu, penulis tertarik untuk mengetahui faktor-faktor yang mempengaruhi pertumbuhan ekonomi Indonesia dengan judul analisis pengaruh kurs, net ekspor, dan penanaman modal asing terhadap pertumbuhan ekonomi Indonesia.

\section{METODE}

Metode yang digunakan dalam penelitian ini adalah metode analisis deskrptif dan kuantitatif.Data yang dipergunakan di dalam penelitian ini merupakan data sekunder yang disajikan dalam bentuk data tahunan atau berkala (time series) mulai dari tahun 1998-2017. Data yang diteliti adalah kurs, net ekspor, penanaman modal asing (PMA), dan pertumbuhan ekonomi Indonesia tahun 1998-2017.

Pengolahan data pada penelitian ini menggunakan program Eviews 7. Alat analisis yang digunakan dalam penelitian ini adalah regresi linear berganda.Analisis regresi linear berganda ini digunakan untuk membahas hubungan lebih dari dua variabel, dengan metode kuadrat terkecil biasa atau Ordinary Least Square (OLS).Analisis dalam penelitian ini adalah analisis deskriptif dan kuantitatif. Analisis deskriptif tersebut menggunakan rumus berikut (Rahardja dan Manurung, 2008): 


$$
G_{t}=\frac{X_{t}-X_{t-1}}{X_{t-1}} \times 100 \%
$$

Keterangan:

$\mathrm{G} \quad=$ pertumbuhan variabel $\square_{\text {D }}$ periode $\mathrm{t}$.

$X_{t} \quad=$ variabel $X_{i}$ periode $\mathrm{t}$.

$X_{\square-1} \quad=$ variabel $\square_{\square}$ periode sebelumnya.

Model persamaan regresi linier berganda pada analisis kuantitatif sebagai berikut

(Junaidi, 2015) :

Dimana :

$\mathbf{Y}=\boldsymbol{\beta}_{\mathrm{o}}+\boldsymbol{\beta}_{1} \mathbf{X}_{1}+\boldsymbol{\beta}_{\mathbf{2}} \mathbf{X}_{2}+\boldsymbol{\beta}_{3} \mathbf{X}_{3}+\varepsilon_{t}$

$\mathrm{Y}=$ Pertumbuhan ekonomi

(persen). $\beta_{\mathrm{o}}=$ Konstanta .

$\mathrm{X}_{1}=$ Kurs (rupiah).

$\mathrm{X}_{2}=$ Net ekspor (juta US\$).

$\mathrm{X}_{3}=$ PMA (juta US\$).

$\varepsilon_{\mathrm{t}}=$ Error (variabel penggangu).

\section{HASIL DAN PEMBAHASAN}

\section{Pertumbuhan ekonomi}

Pertumbuhan ekonomi dapat diartikan sebagai suatu kondisi di mana terjadinya perkembangan GNP atau GDP yang mencerminkan adanya pertumbuhan output per kapita dan meningkatnya standar hidup masyarakat. Berikut ini adalah data pertumbuhan ekonomi Indonesia yang disajikan pada Gambar1 :

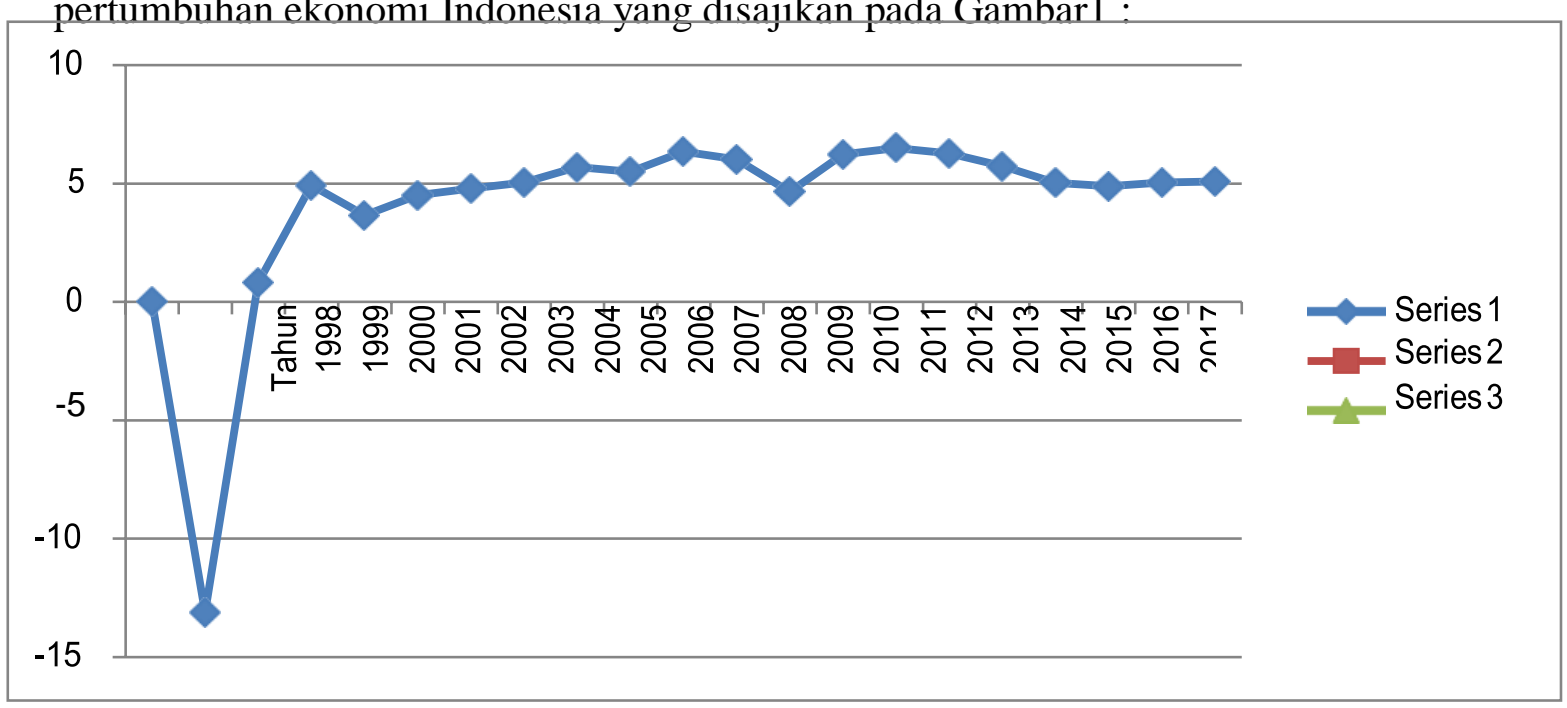

Sumber : BPS Nasional 2018

Gambar 1.Laju pertumbuhan ekonomi Indonesia Tahun 1998-2017 (persen).

Pertumbuhan ekonomi Indonesia periode 1998-2017 mengalami fluktuasi setiap tahunnya. Pertumbuhan ekonomi Indonesia pada tahun 1998 sebesar -13,13\%. pertumbuhan ekonomi paling tinggi terjadi pada tahun 2011 sebesar 6,49\%.Kemudian pada tahun 2017 pertumbuhan ekonomi sebesar 5,07\%.

\section{Perkembangan kurs rupiah}

Kurs dapat diartikan sebagai jumlah suatu mata uang yang diperlukan untuk 
membeli satu satuan mata uang lain. Berikut data perkembangan kurs rupiah yang ditunjukkan pada Gambar 2 :

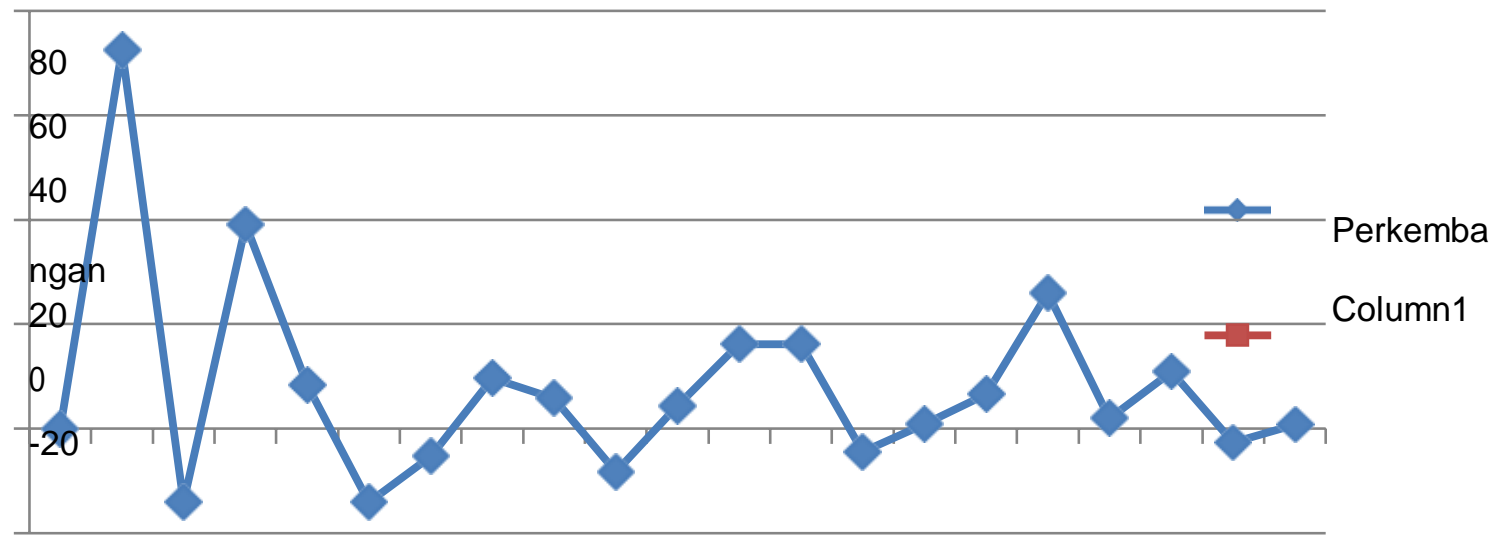

๙

Sumber : BPS Nasional 2018 (Data diolah).

Gambar 2.Perkembangan kurs rupiah (persen).

Perkembangan kurs pada tahun 1998-2017 mengalami fluktuasi, nilai kurs terendah yaitu pada tahun $1999-14,02 \%$ dengan nilai kurs yang mulai terapesiasi menjadi Rp 6.900,-. Depresiasi kurs pada tahun 1999 disebabkan oleh gejolak di pasar uang dan gejolak di sosial politik serta suasana ketidakpastian yang ditimbulkan oleh adanya rencana dan penundaan pelaksanaan sejumlah bank oleh pemerintah dalam rangka rekapitalasi perbankan (Bank Indonesia, 1999). Sedangkan nilai kurs tertinggi terjadi pada tahun 2017 sebesar Rp 13.548 dengan perkembangan sebesar 0,83\%

\section{Perkembangan net ekspor}

Net ekspor adalah nilai ekspor yang dilakukan suatu negara dalam suatu tahun tertentu dikurangi dengan nilai impor dalam periode yang sama (Sukirno, 2011). Berikut data perkembangan net ekspor Indonesia tahun 1998-2017 yang ditunjukkan pada Gambar 3 : .

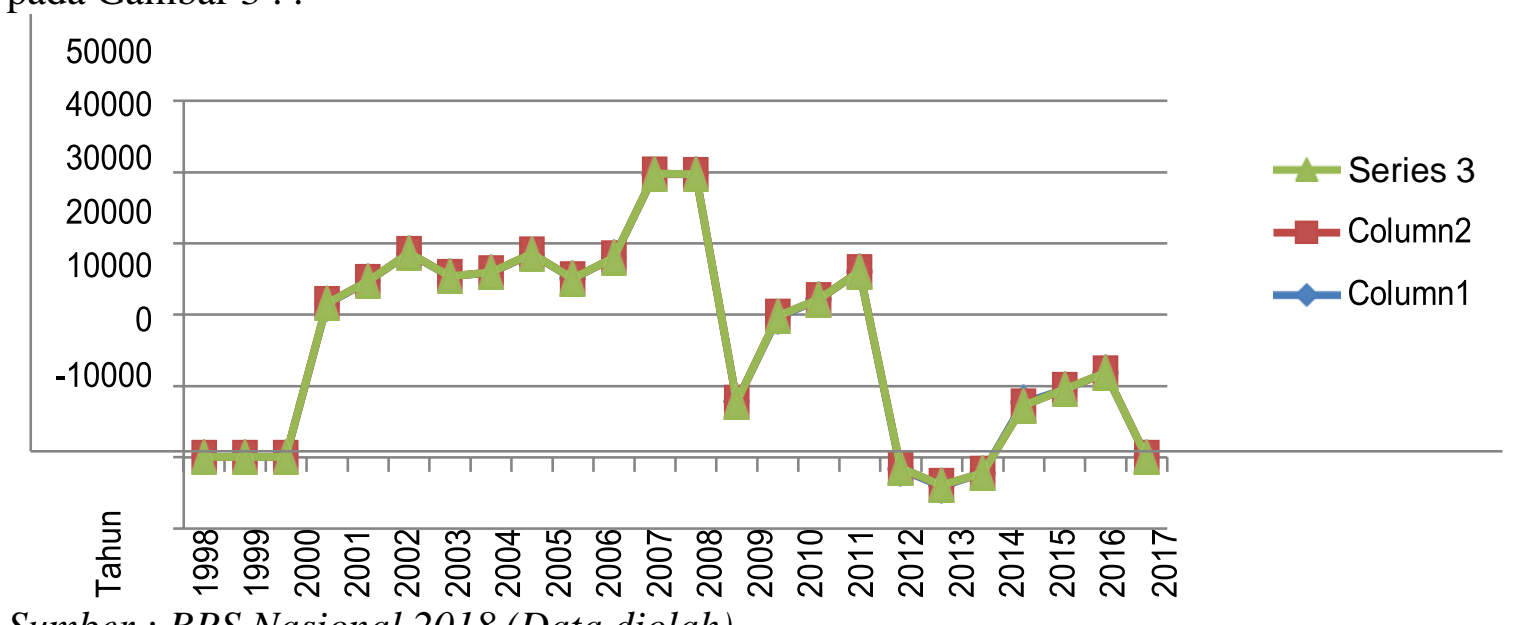

Sumber : BPS Nasional 2018 (Data diolah)

Gambar 3.Perkembangan net ekspor Indonesia (persen).

Perkembangan net ekspor Indonesia dari tahun 1998-2017 mengalami fluktuasi. 
Nilai net ekspor terendah terjadi pada tahun 2012 sebesar US\$ $-1.669,20$ dengan perkembangan sebesar 106,41\%. Menurut Bank Indonesia (2013), net ekspor tahun 2012 yang menurun disebabkan ekspor yang melemah dan perekonomian tergantung kepada permintaan domestik, akibatnya terjadi ketidakseimbangan neraca transaksi berjalan. Selain itu, meningkatkan impor migas dan beban subsidi semakin menambah tekanan defisit transaksi berjalan.Nilai net ekspor tertinggi terjadi pada tahun 2006 sebesar US\$39.733,10 dengan perkembangan sebesar 42,11. Menurut Bank Indonesia (2007), perkembangan net ekspor tahun 2006 disebabkan perbaikan kondisi makroekonomi juga diperkuat kinerja eksternal Indonesia yang semakin mantap, hal ini mengakibatkan kinerja ekspor cukup pesat, sementara impor melambat akibat belum pulihnya permintaan domestik. Membaiknya kinerja ekspor didukung oleh pertumbuhan ekonomi global yang relatif masih kuat dan harga komoditas primer yang masih tinggi di pasar internasional.

\section{Perkembangan Penanaman Modal Asing (PMA)}

Penanaman modal asing (PMA) merupakan suatu usaha yang dilakukan pihak asing dalam rangka menanamkan modalnya di suatu negara dengan tujuan untuk mendapatkan laba melalui penciptaan produk atau jasa (Tan, 2014). Berikut data perkembangan PMA Indonesia tahun 1998-2017 yang ditunjukkan pada Gambar 4 :

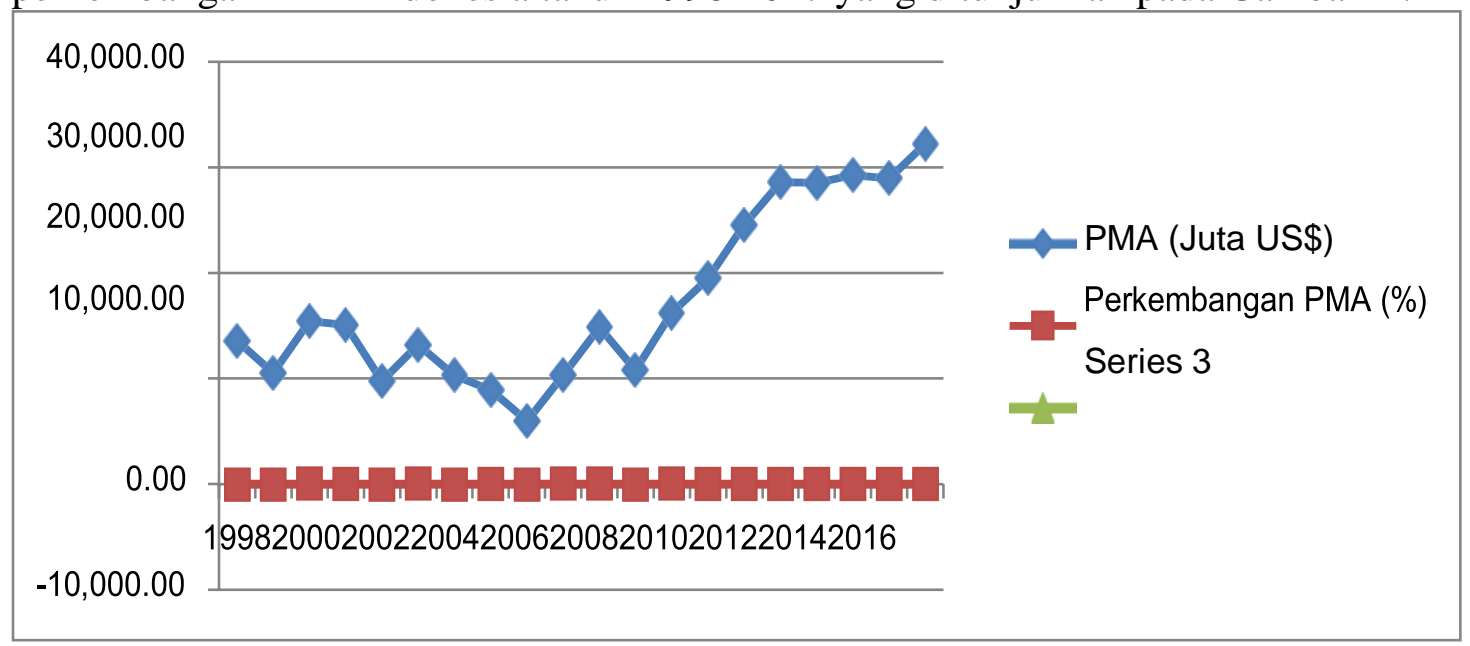

Sumber: BPS Nasional 2018 (Data diolah).

Gambar 4.Perkembangan Penanaman Modal Asing (PMA) Indonesia.

Perkembangan PMA pada tahun 1998-2017 mengalami fluktuasi, nilai PMA terendah terjadi pada tahun 2006 sebesar US\$ 5.977,00 dengan perkembangan sebesar - 32,97\%. Menurut Bank Indonesia (2007), perkembangan PMA tahun 2006 menurun disebabkan kondisi pasar finansial yang masih rentan terhadap pembalikkan arus modal luar negeri, akibat harga minyak dunia yang masih bergerak naik beriringan dengan meningkatnya suku bunga global, sehingga investasi asing melambat. Sedangkan nilai PMA tertinggi terjadi pada tahun 2017 US\$ 32.239,80, dengan perkembangan sebesar $11,31 \%$.

\section{Hasil analisis kuantiatif}

Regresi linear berganda digunakan untuk mengetahui pengaruh variabel bebas, yaitu kurs, net ekspor, dan PMA terhadap variabel terikat, yaitu pertumbuhan ekonomi. Berikut hasil perhitungan regresi linear berganda dengan metode OLS pada Tabel 1. 
Nilai koefisien variabel kurs sebesar0,001441. Hasil yang diperoleh sebesar artinya setiap tambahan kurs sebesar Rp1 per tahun maka pertumbuhan ekonomi akan bertambah sebesar 0,001441, dengan asumsi net ekspor dan PMA tetap.

Nilai koefisien X2 (net ekspor) adalah sebesar -0.000135. Artinyaketika net ekspor bertambah sebesar U\$ 1000 per tahun, maka pertumbuhan ekonomi akan berkurang sebesar -0,000135 per tahun, dengan asumsi kurs dan PMA konstan.

Nilai Kofisien X3 (penanaman modal asing) bernilai negatif, yaitu sebesar 0,134882. Artinya ketika PMA bertambah sebesar U\$ 1000 per tahun, maka pertumbuhan ekonomiakan berkurang sebesar 0,134882 per tahun, dengan asumsi kurs dan net ekspor konstan.

Tabel 1. Hasil regresi linear berganda

\begin{tabular}{llllr}
\hline Variable & Coefficient & Std. Error & t-Statistic & Prob. \\
\hline C X1 X2 X3 & 80.84601 & 18.87546 & 4.283128 & 0.0006 \\
R-squared & 0.001441 & 0.000430 & 3.347734 & 0.0041 \\
Adjusted R-squared & -0.000135 & $7.64 \mathrm{E}-05$ & -1.760318 & 0.0975 \\
S.E. of regression & -21.16791 & 4.348345 & -4.868038 & 0.0002 \\
Sum squared resid & 0.649954 & Mean dependent var & 4.170000 \\
Log likelihood & 0.584320 & S.D. dependent var & 4.257212 \\
F-statistic & 2.744762 & Akaike info criterion & 5.034122 \\
Prob(F-statistic) & 120.5395 & Schwarz criterion & 5.233269 \\
& -46.34122 & Hannan-Quinn criter. & 5.072998 \\
& 9.902753 & Durbin-Watson stat & 1.394844 \\
& 0.000624 & & \\
\hline
\end{tabular}

Sumber : Data diolah 2019(diolah)

\section{Pengujian hipotesis uji F}

Pengujian yang dilakukan untuk mengetahui apakah variabel independen secara bersama-sama berpengaruh terhadap variabel dependen (Patria, 2018). Jika nilai probabilitas $\mathrm{F}$ lebih kecil dari $\alpha=1 \%, 5 \%$, dan $10 \%$ maka secara bersama-sama seluruh variabel independen berpengaruh signifikan terhadap variabel bebas. Nilai Prob. F- statistik adalah sebesar 0,000624. Nilai Prob. F statistik lebih kecil dari $(\alpha=$ $1 \%$ ). Berarti secara bersama-sama variabel kurs, net ekspor, dan PMA berpengaruh signifikan terhadap pertumbuhan ekonomi Indonesia.

\section{Uji t}

Uji t dilakukan dengan tujuan untuk mengetahui besarnya pengaruh masingmasing variabelbebas terhadap variabel terikat (Diar, 2017).Setelah diperoleh nilai Prob. t-statistik dari hasil estimasi metode OLS, nilai Prob. t-statistik dibandingkan dengan $\alpha$ $1 \%$, 5\%, atau 10\%. Jika Prob.t statistik lebih besar dari 1\%, 5\%, atau $10 \%$ maka variabel bebas berpengaruh siginifikan terhadap variabel terikat. Berikut ini hasil uji $\mathrm{t}$ dengan metode OLS:

Nilai Prob.t-statistik X1 (kurs) sebesar 0,0041. Nilai 0,0041 lebih kecil dibandingkan dengan $\alpha=1 \%$. Berarti kurs berpengaruh positif dan signifikan terhadap pertumbuhan ekonomi Indonesia, dengan asumsi variabel net ekspor dan PMA konstan

Nilai Prob. t-statistik X2 (net ekspor) sebesar 0,0975. Nilai 0,0975 lebih kecil dari $\alpha=10 \%$. Artinya net ekspor berpengaruh positif dan signifikan terhadap pertumbuhan ekonomi Indonesia, dengan asumsi kurs dan PMA konstan.

Berdasarkan hasil estimasi yang ditunjukkan pada Tabel 5.2, Prob. t-statistik X3 
(PMA) adalah sebesar 0,0002. Nilai Prob. t-statistik X3 lebih kecil dari $\alpha=1 \%$. Berarti PMA berpengaruh positif dan signifikan terhadap pertumbuhan ekonomi Indonesia, dengan asumsi variabel kurs dan net ekspor konstan.

\section{Koefisien determinan $\left(\mathbf{R}^{2}\right)$}

Koefisien Determinasi $\left(\mathrm{R}^{2}\right)$, yaitu ukuran seberapa besar variasi atau persentasi dari variabel bebas yang mempengaruhi variabel terikat (Diar, 2017). Hasil $\mathrm{R}^{2}$ ditunjukkan pada nilai $\mathrm{R}$-squared yaitu sebesar 0,649954. Artinya nilai $\mathrm{R}^{2}$ sebesar 0,649954 menunjukkan bahwa naik turunnya pertumbuhan ekonomi di Indonesia sebesar 64,9954\% disebabkan oleh naik turunnya kurs, net ekspor, dan PMA. Sisanya sebesar 35,0046\% disebabkan oleh variabel diluar model, selain kurs, net ekspor, dan PMA.

\section{Uji asumsi klasik}

\section{Uji multikoliniaritas}

Uji multikolinearitas berarti adanya hubungan linear (sempurna atau tidak sempurna) diantara beberapa atau semua variabel bebas dalam model regresi.Multikolinearitas juga dapat dideteksi dengan nilai VIF.Aturannya, jika nilai VIF lebih besar dari 10, maka terdapat multikolinearitas dalam model. Berikut hasil nilai VIF yang diperoleh dengan menggunakan eviews yang ditunjukkan pada

Tabel 2.Hasil nilai VIF

\begin{tabular}{cccc}
\hline Variable & $\begin{array}{c}\text { Coefficient } \\
\text { Variance }\end{array}$ & Uncentered VIF & Centered VIF \\
\hline C & 356.2830 & 945.8357 & NA \\
X1 & $1.85 \mathrm{E}-07$ & 52.61040 & 1.755277 \\
X2 & $5.84 \mathrm{E}-09$ & 8.146327 & 2.438003 \\
X3 & 18.90810 & 884.4407 & 2.131005 \\
\hline
\end{tabular}

Sumber : Data diolah 2019

Berdasarkan Tabel 2, dapat diketahui niali VIF dari centered VIF. Nilai VIF X1 sebesar 1,755277, nilai VIF X2 sebesar 2,438003, dan nilai VIF X3 sebesar 2.131005, karena nilai VIF X1, X2 dan X3 lebih kecil dari 10 maka tidak terdapat gejala multikolinearitas dalam model regresi.

\section{Uji autokorelasi}

Uji autokorelasi dilakukan untuk mengetahui ada atau tidaknya korelasi antar anggota serangkaian observasi yang diurutkan menurut waktu (dalam data time series) atau ruang (dalam data cross section).Metode yang dilaukan untuk mendeteksi autokorelasi adalah metode grafik. Berikut hasil dari metode grafik yang ditunjukkan pada Gambar 5 :

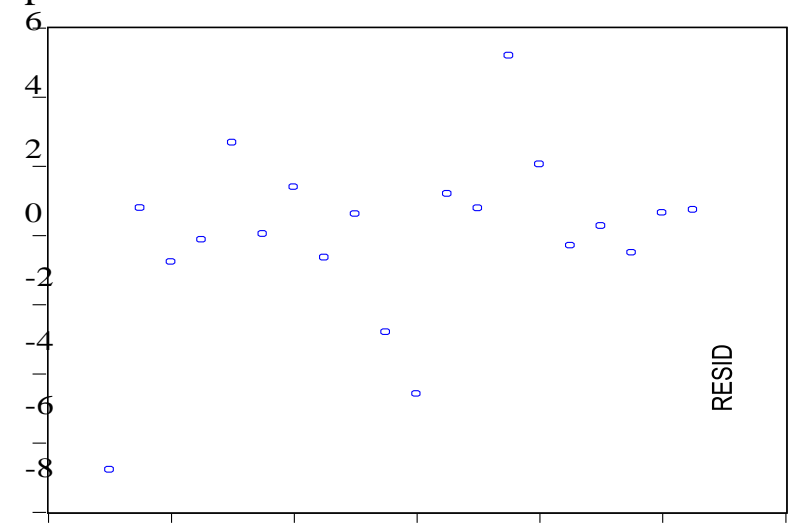


$1,9962,0002,0042,0082,0122,0162,020$

Sumber: Data diolah 2019

Gambar 5. Hasil metode grafik

Berdasarkan Gambar 5. tersebut, diketahui hasil metode grafik yang mana titiktitik pada grafik tersebut tidak membentuk pola atau trend linear, parabolic, ataupun kubik, sehingga tidak terdapat gejala autokorelasi dalam model regresi.

\section{Uji heterokedastisitas}

Metode yang digunakan untuk mendeteksi heterokedastisitas adalah dengan ujiglejser. Asumsinya adalah jika nilai probabilitas $O b s^{*} R$-Squaredlebih besar dari $\alpha$ $5 \%$, maka tidak terdapat masalah heterokedastisitas dalam model Berikut hasil uji white yang ditunjukkan pada Tabel 3 :

Tabel 3. Hasil uji glejser.

\begin{tabular}{|c|c|c|c|}
\hline \multicolumn{4}{|c|}{ Heteroskedasticity Test: Glejser } \\
\hline Obs*R-squared & 3.988248 & Prob. F(3,16) & 0.2627 \\
\hline Scaled explained SS & 4.828648 & $\begin{array}{l}\text { Prob. Chi-Square(3) } \\
\text { Prob. Chi-Square(3) }\end{array}$ & 0.1848 \\
\hline
\end{tabular}

Sumber : Data diolah 2019

Berdasarkan Tabel 3 tersebut, diketahui prob. Chi-square pada Obs*R-Squared yaitu sebesar 0.2627 . Nilai 0,2627 lebih besar dari $\alpha=5 \%$, sehingga tidak terdapat gejala heterokedastisitas dalam model regresi.

\section{Uji normalitas}

Uji normalitas diketahui dengan membandingkan nilai Jarque-Bera (JB) dengan nilai $X^{2}$ tabel atau $=1 \%$ dan $5 \%$ setelah memperoleh hasil uji normalitas melalui estimasi (Patria, 2018). Jika nilai probabilitas JB $>\alpha 5 \%$, maka residualnya berdistribusi normal.Sebaliknya, jika nilai probabilitas JB $<\alpha 5 \%$, makaresidualnya berdistribusi tidak normal. Berikut hasil uji normalitas yang ditunjukkan pada Gambar 6 :

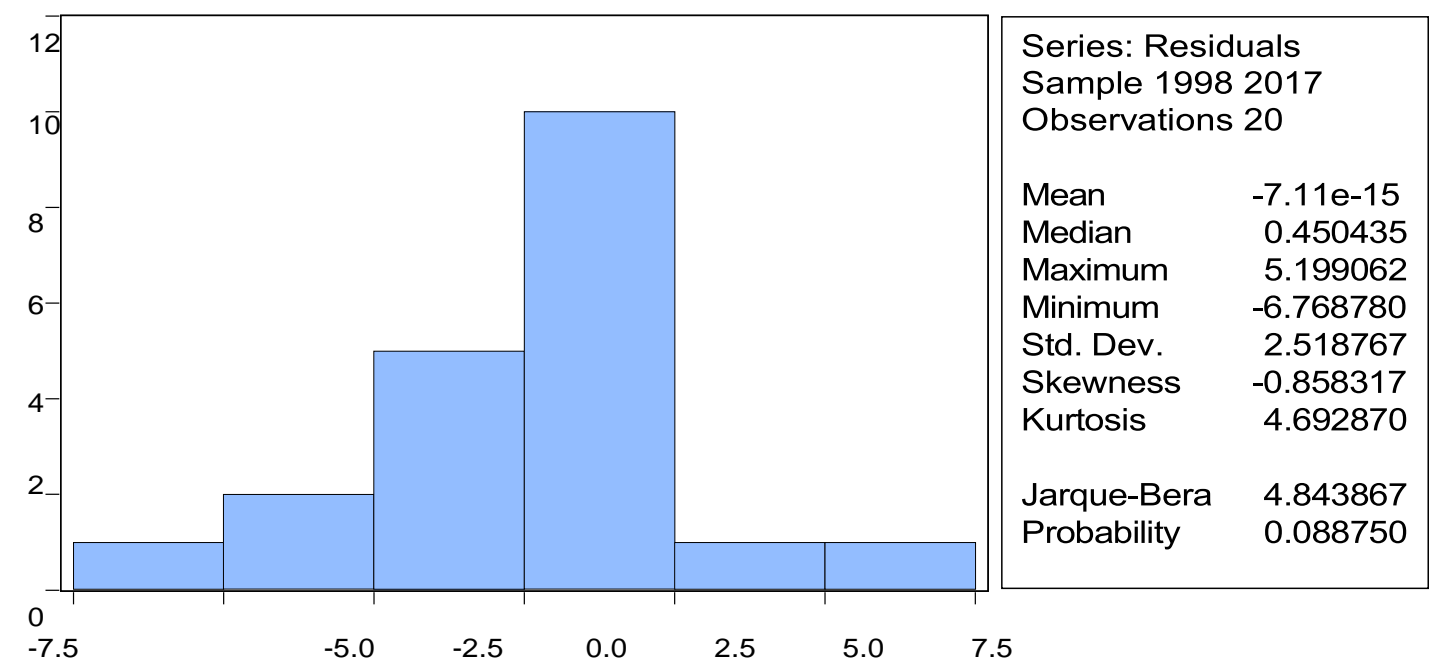

Sumber : Data diolah 2019

Gambar 6. Hasil Uji Normalitas. 
Gambar 6 tersebut, diketahui nilai JB sebesar 4,843867 dengan probabilitas sebesar 0,088750. Nilai probabilitas sebesar 0,088750 ini lebih besar dari $\alpha=5 \%$, sehingga residualnya berdistribusi normal.

\section{Implikasi hasil penelitian}

\section{Pengaruh kurs dengan pertumbuhan ekonomi Indonesia}

Hasil penelitian ini menunjukkan kurs berpengaruh positif dan signifikan terhadap pertumbuhan ekonomi. Penelitian sejalan degan penelitian penelitian yang dilakukan Hatane Semuel dan Stephanie Nurina (2015), mengenai Analysis of the Effect of Inflation, Interest Rate, and Exchange Rates on Gross Domestic Product (GDP) in Indonesia. Penelitian ini menyatakan bahwa Tingkat suku bunga berpengaruh negatif signifikan terhadap PDB dan nilai tukar berpengaruh positif signifikan positif signifikan terhadap PDB.

\section{Pengaruh net ekspor terhadap pertumbuhan ekonomi Indonesia}

Hasil penelitian ini menunjukkan net ekspor berpengaruh positif dan signifikan terhadap pertumbuhan ekonomi.Net ekspor yang dilakukan suatu negara akan berdampak positif terhadap pertumbuhan ekonomi, apabila nilai ekspor lebih besar daripada nilai impor sehingga akan meningkatkan pendapatan nasional dan pertumbuhan ekonomi, dan sebaliknya (Purwanggono, 2015).Penelitian sejalan dengan penelitian yang dilakukan Listiani (2013) mengenai analisis pengaruh net ekspor, investasi, dan pengeluaran pemerintah terhadap pertumbuhan ekonomi di Indonesia tahun 1990-2011 menyatakan bahwa variabel net ekspor memiliki pengaruh yang positif terhadap pertumbuhan ekonomi di Indonesia.

\section{Pengaruh penanaman modal asing (PMA)terhadap pertumbuhan ekonomi}

Hasil penelitian ini menunjukkan PMA berpengaruh positif dan signifikan terhadap pertumbuhan ekonomi. Dengan semakin besarnya PMA, maka diharapkan akan mendorong pertumbuhan sektor swasta dan rumah tangga dalam mengalokasikan sumber daya yang ada di suatu negara. Kemudian akan menyebabkan makin meningkatnya PDB dan diharapkan pertumbuhan ekonomi suatu negara dapat meningkat (Yenti, 2018). Penelitian ini sejalan dengan penelitian yang dilakukan Penelitian yang dilakukan Syaharani (2011) mengenai pengaruh penanaman modal dalam negeri, penanaman modal asing, dan utang luar negeri terhadap pertumbuhan ekonomi di Indonesia periode 1985-2009 menyatakan bahwa variabel penanaman modal asing memiliki pengaruh positif terhadap pertumbuhan ekonomi di Indonesia. Artinya semakin tinggi penanaman modal asing yang masuk, maka semakin tinggi pertumbuhan ekonomi Indonesia, dansebaliknya.

\section{KESIMPULAN DAN SARAN}

\section{Kesimpulan}

Perkembangan kurs, net ekspor, PMA, dan pertumbuhan ekonomi Indonesia selama periode waktu 1998-2017 mengalami fluktuasi. Peningkatan dan penurunan tersebut disebabkan kondisi perekonomian dunia yang sedang stabil atau lemah, kondisi perekonomian nasional, sosial, politik, keamanan, infrastruktur dalam negeri, serta sikap pemerintah dalam memutuskan kebijakan yangdilakukan.

Berdasarkan hasil pengujian menggunakan metode OLS menunjukkan secara 
bersama-sama variabel kurs, net ekspor, dan PMA terhadap pertumbuhan ekonomi Indonesia berpengaruh signifikan. Sedangkan secara parsial, kurs, net ekspor, dan PMA berpengaruh positif dan signifikan terhadap pertumbuhan ekonomi Indonesia.

\section{Saran}

Peningkatan perkembangan kurs, net ekspor, PMA, dan pertumbuhan ekonomi memerlukan kebijakan yang tepat dalam menangani masalah yang akan timbul akibat ekonomi global maupun perekonomian dalam negeri. Variabel kurs, net ekspor, dan PMA dalam penelitian ini berpengaruh signifikan terhadap pertumbuhan ekonomi, maka diharapkan pemerintah memberikan perhatian khusus kepada ketiga variabel tersebut agar dapat memberikan pengaruh yang positif kepada pertumbuhan ekonomi Indonesia.

Pemerintah diharapkan lebih memperhatikan indikator makroekonomi yang dapat menjadi pemicu krisis dan segera mengambil keputusan yang efektif, sehingga dampak krisis terhadap perekonomian Indonesia dapat segeradiatasi.

\section{DAFTAR PUSTAKA}

Annisa Selma Timur. (2018). Analisis faktor-faktor yang mempengaruhi PDB Negara ASEAN Tahun 2006-2016 menggunakan regresi data panel.Skripsi. Yogyakarta : Universitas Islam Indonesia.

Badan Pusat Statistik. (2016). Kurs tengah beberapa mata uang asing terhadap rupiah di Bank Indonesia dan Harga Emas di Jakarta, 2000-2017. BPS : Indonesia.

Bank Indonesia. (2014). Laporan tahunan : berbagai tahun terbitan. Bank Indonesia: Jakarta.

Diar,Destri Tama Arum.(2017 Analisis faktor-faktor yang mempengaruhi ekonomi di Indonesia 1986-2014.Skripsi.Universitas Muhammadiyah Surakarta: Fakultas Ekonomi dan Bisnis)

Hastuti.D; Edhie,Purnawan,M;\& S.Sunargo. (2018). Pengaruh variabel-variabel di sektor riil dan perbankan terhadap Shock Credit Default Swap (CDS) di Indonesia, e-Journal Perdagangan Industri dan Moneter, 6(2), 62-80

Listiani, Yusi. (2013). Analisis pengaruh net ekspor, investasi, dan pengeluaran pemerintah terhadap pertumbuhan ekonomi di Indonesia Tahun 1990-2011. Artikel Ilmiah. Fakultas Ekonomi: Kendari.

Mustika,C; Umiyati,E; \& Achmad,E. (2015).Analisis pengaruh ekspor neto terhadap nilai tukar rupiah terhadap dolar Amerika Serikat dan pertumbuhan ekonomi di Indonesia, Jurnal Paradigma Ekonomika 10 (2)

Nugroho, Prasetyo Ardi. (2016). Analisis ekspor, kurs, dan tingkat suku bunga terhadap nilai pendapatan domestik bruto Indonesia. Jurnal Universitas Muhammadiyah.

Purwanggono, C. Hendra. (2015). Analisis ekspor netto, tenaga kerja, dan investasi terhadap pertumbuhan ekonomi Indonesia. Skripsi. Fakultas Ekonomika dan Bisnis: Semarang.

Rahardja Prathama dan Mandala Manurung. (2008). Teori ekonomi makro: suatu pengantar. Universitas Indonesia : Fakultas Ekonomi Universitas Indonesia

Semuel Hatane dan Stephanie Nurina.(2015). Analysis of the inflation, interest rate, and exchange rates on Gross Domestic Product (GDP) in Indonesia. Proceedings of the Internasional Conference on Global Business, Economics, Finance and Social Sciences (GB15 Thai Conference) 
Sukirno, Sadono. (2011). Makroekonomi teori pengantar edisi ketiga.PT Raja Grafindo Persada : Jakarta

Syaharani, Febrina Rizki. (2011). Pengaruh penanaman modal dalam negeri,penanaman modal asing, dan utang luar negeri terhadap pertumbuhan Ekonomi di Indonesia Periode 1985-2009. Skripsi. Universitas Islam Negeri Syarif Hidayatullah : Fakultas Ilmu Ekonomi dan Bisnis.

Yenti, Saprita. (2018). analisis pengaruh penanaman modal asing, penanamna modal dalam negeri dan ekspor terhadap produk Domestik Bruto Indonesia. Skripsi. Universitas Jambi : Fakultas Ekonomi dan Bisnis.

Yudiarti,T; Emilia,E; \& Mustika,C. (2018).Pengaruh utang luar negeri, tingkat suku bunga dan neraca transaksi berjalan terhadap nilai tukar Rupiah terhadap Dolar Amerika Serikat, e-Jurnal Perdagangan Industri dan Moneter 6 (1), 14-22

Zakaria, Junaiddin. (2009). Pengantar teori ekonomi makro. Gaung Persada Press: Jakarta. 